\title{
The Aulikaras and Their Associates
}

\section{The Early Aulikara Dynasty}

The ruling houses participating in the Aulikara power network begin with the dynasty of Jayavarman, commonly referred to as the Early Aulikaras. Direct epigraphic evidence is extant for three successive kings of this dynasty, beginning with Naravarman around 404 CE. Naravarman's two inscriptions from Bihar Kotra (A2, A3) name his father Simhavarman, and his Mandsaur inscription (A1) further reveals that his grandfather was named Jayavarman. It is possible, pending further research, that some graffiti in Bihar Kotra (B1) refer to these predecessors; and a single copper coin with Simhavarman's name (B2) has been reported without a recorded provenance. No further facts are known about the forebears of Naravarman. Haraprasad Shastri (1914) has suggested that Simhavarman may be identical to another Simhavarman, the father of Candravarman whose brief rock inscription has been found in Susunia ${ }^{24}$ (Bankura District, West Bengal), but this identification is unlikely in view of the geographical distance and the lack of positive evidence.

D. R. Bhandarkar (1913,162and CII3revp. 263) attempted to prove that one of the terms of adulation applied to Naravarman in his Mandsaur inscription means that Naravarman professed fealty to Candragupta II. The expression simhavikrānta-gämin (15), meaning "moving with the bold stride of a lion," is laden with a secondary meaning according to Bhandarkar: Candragupta II is known from coins to have used the epithet simha-vikrama, so the epigraph implies that Naravarman "goes [for refuge] to the person [Candragupta] with the bold advance of a lion." While it does seem possible that Naravarman was a subordinate ally to Gupta power (and perhaps obtained Daśapura as a result of his aid rendered to the Guptas against the Sakas), the inscription is not sufficient evidence to infer this. The reason for the author's choice of the compound simha-vikrānta-gāmin was clearly to echo the name of Naravarman's father Simhavarman introduced in this verse, in close parallel to the way he plays in the previous stanza by describing the grandfather Jayavarman as a narendra (an Indra among men, i.e. a ruler), then comparing Naravarman's valour to that of devendra (the Indra of the gods). ${ }^{25}$

24 Reported by Vasu (1895) and re-edited by Haraprasad Shastri (1915).

25 Jagannath Agrawal (cited, probably from personal communication, by A. Agrawal 1989, 262 n. 6) further noted a literary parallel: the adjective mrgendra-gāmin, "moving like a lion," is used innocuously in Raghuvamśa 2.30 .
The Gangdhar inscription of Mayūrākșaka (A4) was composed during the reign of Naravarman's son Viśvavarman - probably $431 \mathrm{CE}^{26}$ - and the Mandsaur inscription of the silk weavers (A6) mentions that Viśvavarman's son Bandhuvarman was ruling in Daśapura in 436 CE. We thus know about five successive kings, descended father to son, in the Early Aulikara house, but after Bandhuvarman this line disappears from view. Curiously, the silk weaver inscription says nothing about the ruler in the year $473 \mathrm{CE}$, when this inscription was created. This, along with other allusions in that inscription, suggests troubled years in Daśapura and the North Indian world at large; see page 95 for a brief overview. The Mandsaur inscription of Dattabhata (A5), dated ca. 467 CE (and thus preceding the silk weaver inscription only by five years) records a king named Prabhākara allied to the Guptas. Prabhākara may have been a descendant of the Early Aulikara house but, as discussed on page 81, it seems more likely that he had no ties to this dynasty. The Pādatāditaka of Śyāmilaka, datable to sometime in the fifth century, ${ }^{27}$ mentions a man of Daśapura named Rudravarman, whose name suggests that he may be a ruler of the Early Aulikara family. Sadly, there is no way of telling whether he was a purely literary figure or a historical one, and the play at one point describes him as a poet, ${ }^{28}$ so the varman name may be serendipitous.

\section{The Later Aulikaras}

In the early sixth century Prakāsadharman and his (probably immediate) successor Yaśodharman attained great power, claiming to have defeated the Hūna invaders Toramāna and Mihirakula in turn. Yaśodharman has long been known to scholarship as an Aulikara, and when the same name became attached to Naravarman (see page 24), the assumption followed naturally that Yaśodharman was a scion of Naravarman's dynasty (e.g. Majumdar 1954, 39; Sircar 1965b, 413 n. 1). ${ }^{29}$ The discovery of the Risthal

26 The generally accepted date of this inscription is ca. 424 CE. See page 60 for my arguments for a revised date.

27 See Dezső and Vasudeva (2009, xvii-xix) for a summary of opinions about this play's date.

28 Pādatāditaka p. 24, dāśerako rudravarmā; p. 156, anena kavinā dāśerakeṇa rudravarmaṇā.

29 It was in fact even suggested (D. Sharma 1943) that his true name was Yaśovarman, and the $v$ in his name was mistakenly engraved (or read) as $d h$, since the two characters have a similar appearance. Given that the spelling dharman is attested in four instances in three separate inscriptions (counting the two copies of 


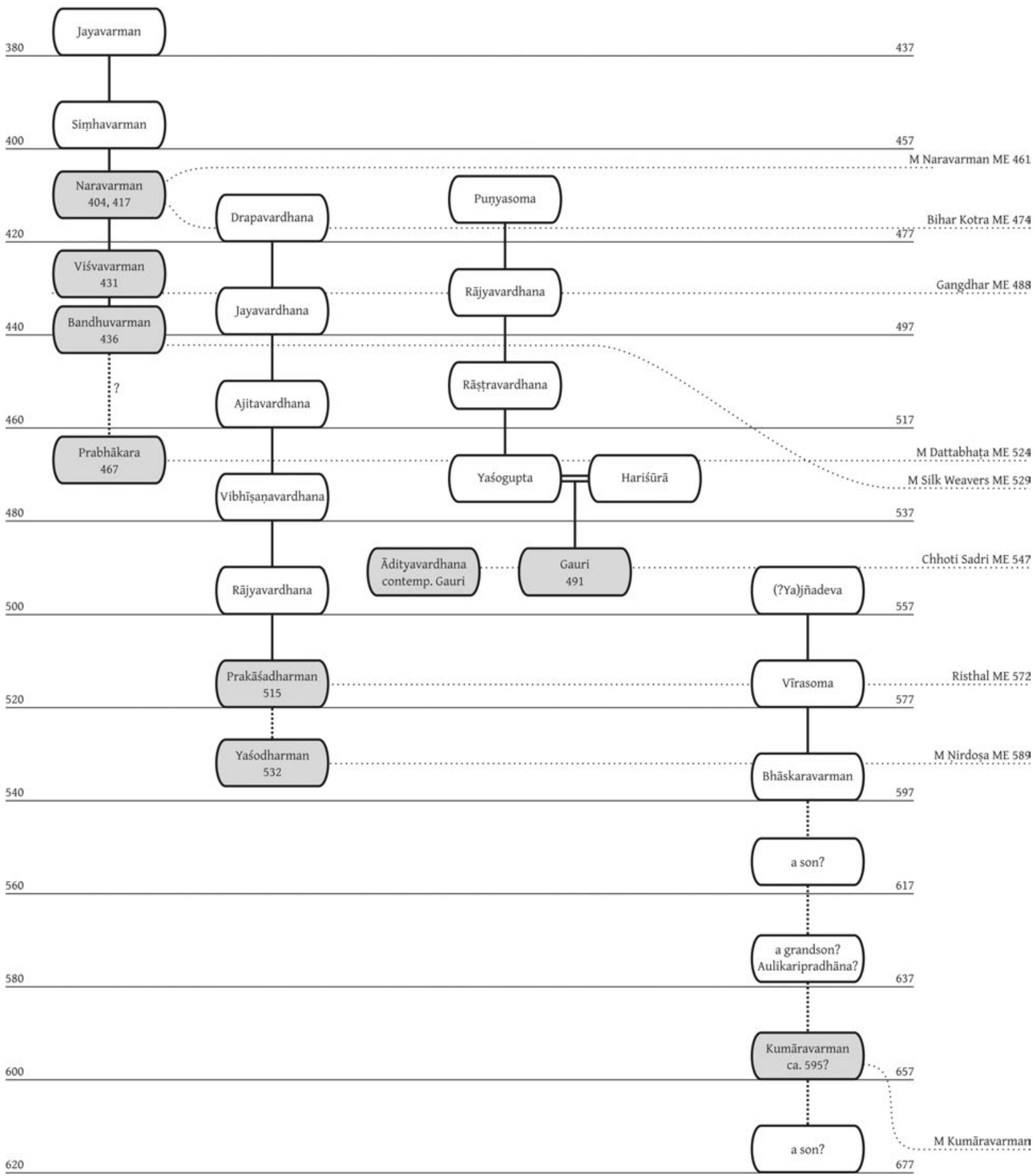

Figure 5: Genealogies of Aulikara and associated ruling houses.

Approximate dates shown in CE on left and ME on right, datable inscriptions labelled on far right. Rulers whose reign is mentioned in an inscription are shown in shaded fields, connected by dotted lines to the inscriptions mentioning them. The reigns of rulers in white fields are estimated, assuming 20 years per generation. Solid vertical lines indicate father-to-son descent, dotted lines show uncertain descent. 
inscription (A9) in 1983 put an end to such hypotheses, since it belongs to Prakāśadharman (another king with a dharman name) and recounts five generations of ancestors before him. Hence these rulers have come to be labelled the "Later Aulikaras," while Naravarman and his kin are now named "Early Aulikaras." I retain this convention here, though if it should ever be proven decisively that Kumāravarman's dynasty was also an Aulikara one, the name "Later Aulikara" would better apply to them. To prevent a confusing scenario like that involving the Later Guptas and Latter Guptas, we should perhaps call Yaśodharman's line the Great Aulikaras or even Imperial Aulikaras, and reserve the tag Later Aulikara for Kumāravarman's dynasty.

The two Aulikara lines overlap in time: Bandhuvarman predates Prakāśadharman by about eighty years, corresponding to three or four generations (see Figure 5), but none of Prakāśadharman's five predecessors have names that satisfactorily match Early Aulikara names. It thus appears that the Later Aulikara line was not directly descended from the Early one, though the possibility cannot be excluded altogether. We now know that Yaśodharman definitely bore the additional name Viṣnuvardhana. ${ }^{30}$ It is conceivable that other members of the dynasty likewise used two (or more) names, and only the paucity of epigraphic evidence is to blame for our lack of information. Thus, the varmans of the Early Aulikara dynasty might have had alternative names in vardhana, and Drapavardhana, the progenitor of the Later Aulikara line, might have been identical to one of the Early Aulikara rulers. However, any such hypothesis ${ }^{31}$ is based solely on speculation, without any factual evidence.

If we adopt the less fanciful hypothesis that the two lines were separate (though probably related ${ }^{32}$ ), then an explanation needs to be found for the fact that ancestors of Prakāśadharman - who must have coexisted with some Early Aulikara kings - are nonetheless given royal titles in the Risthal inscription. As Salomon (1989, 22-23) points out, the actual inscriptional dates of kings do not overlap at any point, so it is safe to assume that the rulers

the Sondhni pillar inscription separately), this suggestion may be safely disregarded.

30 Perhaps as a regnal name distinct from his birth name, see page 164. 31 One may for instance be tempted to put an equal sign between the Early Aulikara Jayavarman and the Later Aulikara Jayavardhana. However, in addition to the total lack of positive evidence, all the later Aulikaras between Jayavardhana and Prakāśadharman would have had to reign for tremendously long periods (and beget heirs at very advanced ages) for this to be possible.

32 As I suggested above (page 25), Drapavardhana may have been one of Naravarman's sons. whose inscriptions are known from any particular period were dominant at the given time. In other words, the early members of the Later Aulikara dynasty were petty local rulers or subordinate governors in the days of Naravarman, Viśvavarman and Bandhuvarman..$^{33}$ In a similar vein but with a different focus, Joanna Williams (2004, 133; probably influenced by Mirashi 1984a, 317) suggests that the two Aulikara houses might have been geographically separate at this time.

Nothing particular is known about the first five rulers of the Later Aulikara house, though the founder Drapavardhana may be identical to a king mentioned by the name Dravyavardhana in the Bṛhatsaṃhitā of Varāhamihira; see page 140 for a discussion of this issue. Prakāśadharman, the first of these kings of whose reign we actually have epigraphic evidence, expresses great pride over his victory against Toramāna in his Risthal inscription (dated ca. $515 \mathrm{CE}$ ), and also boasts of several great construction projects carried out in the city of Daśapura.

As for Yaśodharman, we have his own undated pillar inscription (inscribed in duplicate) from Sondhni (A11, A12), commemorating another victory against the Hūnas represented this time by Mihirakula; and a stone inscription of his reign dated ca. $532 \mathrm{CE}$, by the Naigama potentate Nirdoșa (A10). According to the inscription of Nirdoșa, Yaśodharman bore the alternative name Viṣnuvardhana, ${ }^{34}$ and both epigraphs give him imperial titles (rājādhirāja-parameśvara in the stone inscription and samrāj in the Sondhni pillar). We have no record of Prakāśadharman's relation to Yaśodharman, but, as Salomon $(1989,12)$ notes, there is "absolutely no doubt" that they belonged to the same line, ${ }^{35}$ and it is "beyond reasonable doubt" that the former is the latter's immediate predecessor and most probably his father. In addition to their proximity in time and the fact that they are the only two known Aulikara rulers with names in dharman, they are also linked by their courtiers. The poet Vāsula composed both the Risthal inscription and the Sondhni inscription, while Prakāśadharman's chancellor Doșa (alias Bhagavaddoṣa, see page 165) was the uncle

33 Salomon's reasoning also extends to Gauri, who he suggests was dominant around $491 \mathrm{CE}$, and to Kumāravarman (see page 32). The former presupposes the identity of Gauri and Ādityavardhana, which is highly doubtful (see page 128).

34 Some scholars including Fleet himself (e.g. CII3, 155 n. 5) have understood the inscription to mean that Yaśodharman and Viṣnuvardhana were separate personages. This hypothesis is extremely unlikely and can safely be discarded; see page 164 for a discussion. 35 Formerly, Williams $(1972,51)$ had proposed that Yaśodharman was an offspring of a union of the Early Aulikara house with the Mānavāyanis, but this may be discarded in light of the Risthal inscription. 
(or father) and predecessor in office of Yaśodharman's chancellor Dharmadoșa.

After Yaśodharman, the Later Aulikara dynasty disappears from view. There is a slight possibility that the dynasty of Kumāravarman (page 32) is a continuation of this line, but there are at present more indications against this than for it.

\section{The Naigamas}

The Later Aulikaras were closely associated with another powerful family, widely referred to as the Naigamas, who provided hereditary chancellors (räjasthānīya) ${ }^{36}$ to the Later Aulikara royalty. We have abundant information about members of this lineage, mostly from the Mandsaur stone inscription of Nirdoșa (A10), but also from the Risthal inscription (A9) and the Chittorgarh fragment (A13, A14). The inscriptions, unfortunately, do not make Naigama family relations sufficiently clear (see Figure 6 for the generally accepted interpretation and an alternative reconstruction of the genealogy, and page 165 for a discussion), but the fact that several generations of Naigamas have served several generations of Aulikara kings in a ministerial function is certain. The Mandsaur stone records that the founder of the family was a tycoon named Sasthidatta, who took refuge at the feet of Yaśodharman's ancestors, though this does not necessarily mean occupying the position of rājasthānìya. His son Varāhadāsa is mentioned in the same inscription, as well as (probably) in the Chittorgarh fragment, which also speaks of a man named Viṣnudatta who may have been one of Varāhadāsa's sons. ${ }^{37}$ From the Risthal inscription we learn that Șașthidatta's grandson (or great-grandson depending on how the genealogy is reconstructed) Doșa ${ }^{38}$ was Prakāśadharman's chancellor, and that Doșa's father was also chancellor to a predecessor of Prakāsadharman. The word rājasthāniya also appears in the Chittorgarh fragment, but who it applies to is not clear. Finally, according to the Mandsaur inscription, Doșa's successor in office was his younger brother Abhayadatta, who in turn was

36 See page 8 about the translation of this term.

37 Interestingly, the Pādatāditaka of Śyāmilaka (5th century), mentions a minister named Viṣṇudāsa (p. 24, amātyo viṣnudāsaḥ) in the same breath as Rudravarman of Daśapura (q.v. page 27 with note 28); and a person named Varāhadāsa at another place (p. 130). Either or both of these may be coincidental similarities.

38 Referred to as Bhagavaddoṣa elsewhere in scholarly literature. See page 165 for my reasons to understand only Doșa as his name. succeeded by Doșa's son (or, in the conventional interpretation, niece) Dharmadoșa.

The family's appellation is drawn from lines $10-11$ of the Mandsaur inscription, which speaks of a "dynasty of Naigamas" (anvavāyo ... naigamānām). The word may mean either an interpreter of scripture (from nigama in the sense of a Vedic text), or a merchant (from nigama in the sense of a marketplace or merchant group). Fleet (CII3, 152) understood it in the former sense, but since the expression vanijām śreștho, "best of merchants," is applied in the Chittorgarh fragmentary inscription to a member of (almost certainly) the same family, Sircar and Gai (1961, 54 n. 3) have pointed out that the latter is far more likely to be correct, and this has become the generally accepted view (Salomon 1989, $33 \mathrm{n}$. 11). The Naigamas thus started out as men of commerce, and naigama may simply be a description of the family profession. However, since we have no record of any other proper name for them, I continue here the widely adopted practice of using Naigama as their family name. Whether they had a different family name or not, the appellation naigama has an interesting corollary that to my knowledge has not been raised before: it seems possible that the Naigama chancellors were descendants of the silk weavers who, according to their inscription of 473 CE (A6) moved to Daśapura from the land of Lāta and then diversified into a variety of occupations. See page 98 for further discussion.

\section{The Mānavāyanis}

This dynasty is known through two inscriptions of a single ruler named Gauri. ${ }^{39}$ A complete and fairly long inscription found in Chhoti Sadri (A7) preserves his genealogy to four generations of ancestors, and a fragmentary epigraph from Mandsaur (A8) records a shorter genealogy. Only the Chhoti Sadri inscription bears a date (ME 547, ca. 490 CE), which indicates that Gauri flourished in the interregnum during which "other kings" ruled Daśapura according to the inscription of the silk weavers (A6). The same inscription also mentions a rājaputra Gobhața, who may have been Gauri’s son.

39 Gauri is quite peculiar for a male name. One might be tempted to assume that it is a misreading or erroneous engraving of Śauri, since $s$ differs from $g$ only in a small detail in the script of the pertinent inscriptions. The report of the Chhoti Sadri inscription (IAR 1953-54, 13) already suggested emendation to Sauri, but $g$ is distinctly clear in both of the inscriptions that record this name. A misreading can thus be ruled out, and the chance that the same scribal mistake was committed in two separate inscriptions is negligible. 


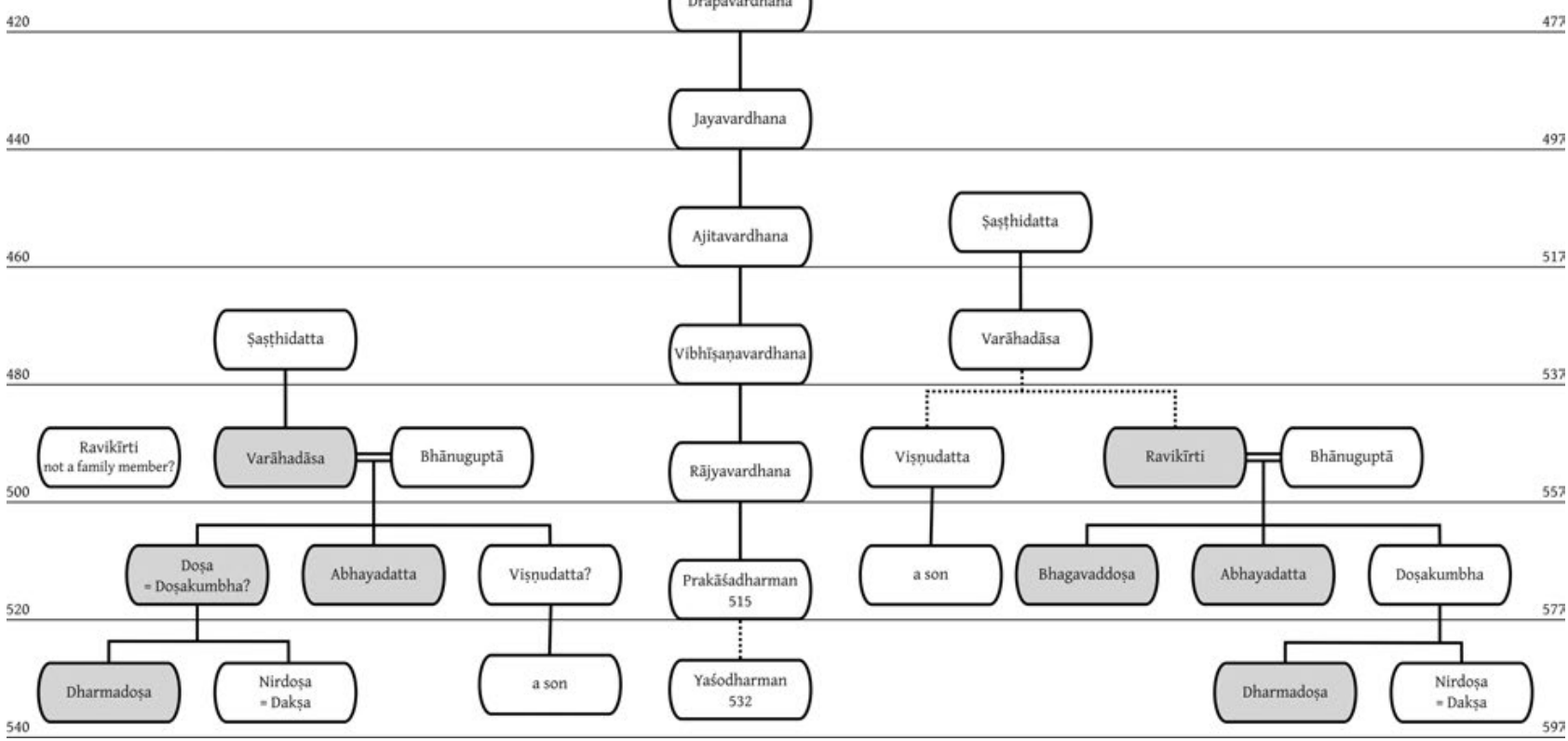

Figure 6: Possible genealogies of the Naigama family. Approximate dates shown in CE on left and ME on right. The tree to the left of the Later Aulikara line shows my proposed reconstruction (discussed on page 165); the tree on the right shows a conventional reconstruction. Persons described as rājasthānīya or amātya in inscriptions are shown in shaded fields. Dates of the ancestors of Doșa/Bhagavaddoșa are estimated assuming 20 years per generation. Solid vertical lines indicate father-to-son descent, dotted lines show uncertain relations.

No unequivocal dynastic name is recorded for these rulers, ${ }^{40}$ but they are said in the Chhoti Sadri inscription to originate from the Mānavāyani clan (kula). As Sircar (1954b, 122) notes, the standard spelling would probably be Mānavāyani, implying descent from Manu Svāyaṃbhuva and reminiscent of the gotra name Mānavya, which has been claimed on several occasions by ruling houses presumed to be of non-Aryan origin..$^{41}$ The incompletely preserved characters māna in the Mandsaur fragment may also be an indication that they professed to be of the Mānava gotra (what remains of the context implies a gotra or family name here; mānavya, however, would be metrically impossible).

40 G. H. Ojha $(1930,2)$ believed that the name of the dynasty was Gaura. I fully agree with Sircar (1954b, 122) in rejecting this and interpreting the word gaura (A7, line 4) simply as "bright" in the sense of prestigious.

41 Most notable among such dynasties are the Kadambas, but closer to Daśapura, the early Gujarat Cālukyas also made this claim around the turn of the 8th century, for example in the Navsari plates of Śryāśraya Sîlāditya (Mirashi 1955, 123-27).
Gauri's ancestry includes two men with names ending in vardhana, but the line does not appear to be connected to that of the Later Aulikaras. The name of Gauri's great-grandfather is Rājyavardhana, which is also the name of Prakāśadharman's father. However, since Gauri's clearly legible date precedes Prakāśadharman's equally clear date by twenty-four years, the two Rājyavardhanas cannot have been identical. Another of his ancestors has a name ending in soma, which may link Gauri's family to the Nandsa yūpa inscriptions (see page 19) and to the predecessors of Kumāravarman (see below). The use of a shared name ending does not, of course, prove a direct connection, but it does imply that Gauri's family was likewise of Mālava extraction rather than an outsider clan.

Gauri's Mandsaur fragment mentions a king named Adityavardhana, whose identity is uncertain. It is possible that Ādityavardhana was another name of Gauri, but what appears more likely is that he was a sovereign ruler to whom Gauri owed allegiance, possibly a member of an Aulikara family. This question is discussed on page 128. 


\section{The Dynasty of Kumāravarman}

A single fragment of a large stone slab (A15), discovered about the same time as the Risthal inscription, preserves the name of Kumāravarman and his ancestors, none of whom are known from any other source. The single published edition of this Mandsaur stone inscription of Kumāravarman (Mirashi 1983) heavily underestimated the amount of lost text at the beginning of each line of the epigraph, as a result of which the accepted genealogy of Kumāravarman needs to be revised: $:^{42}$ there were probably more generations mentioned in the inscribed account than previously assumed. Rather than four generations including Kumāravarman, the long praśasti in my opinion records the deeds of no fewer than five, and probably as many as seven generations of rulers (see Figure 5 on page 28).

The epigraph has no extant date, but it mentions a certain "son of Kṛṣna" who attacked Kumāravarman and was slain by him. The attacker was quite certainly the Kalacuri Śankkaragaṇa, son of Kṛ̣narāja, who is associated with an inscriptional date of 595 CE. The palaeography of the Kumāravarman inscription matches that period; if I am correct in hypothesising that the commissioner of the inscription was actually Kumāravarman's son, then its probable date is in the first or second decade of the seventh century.

Kumāravarman's praśasti mentions Daśapura in a context that, though partly lost, implies that it was the royal seat of this dynasty (verses 29-30). It also mentions someone who was foremost among Aulikara descendants (aulikari-pradhāna, see also page 24 above), but the context of this word is even less well preserved. It has been suggested that a member of Kumāravarman's dynasty defeated this Aulikara scion (Mirashi 1983, 71), or that he pleased the

42 See my commentary on the inscription for details, and page 212 for the thought process that led me to the conclusion that the original stone had been much wider than assumed.
Aulikara lord as a vassal (Sircar 1984b, 392). In my opinion the most likely restoration is that he sired a son who was foremost among the Aulikara progeny, but Sircar's suggestion cannot be ruled out. See page 207 for my reasoning.

It follows from this that Kumāravarman's house was connected to the Aulikaras not only by the fact that they ruled Daśapura after Yaśodharman's time, but by blood as well. The conventional count of Kumāravarman's forebears (Salomon 1989, 15) puts his dynasty's progenitor (Ya?)jñadeva in the same rough time bracket as Yaśodharman, in the second quarter of the sixth century. But if my estimate of the number of generations for whom we have no extant names is correct, then (Ya?)jñadeva instead flourished two generations earlier, in the last quarter of the fifth century or about the same time as Gauri.

By this count then, there is a temporal overlap between the Later Aulikaras and Kumāravarman's line, with the implication that Kumāravarman cannot have been a descendant of Yaśodharman since the names in the two genealogies do not match. Not only are there no exact matches or close resemblances, there is not even a name ending in vardhana among Kumāravarman's ancestors; nor would it be likely for a descendant of Yaśodharman not to include his glorious ancestor in his praśasti. There are, however, two varmans in his genealogy (including Kumāravarman himself), and there is also a soma, which may imply kinship with the line of Gauri. However, if I am correct in assuming that the kings of Kumāravarman's dynasty called themselves Aulikaras, then descent from the Mānavāyani line is unlikely. ${ }^{43}$ It does, however, seem possible that these kings were direct descendants of the Early Aulikara line, which favoured names in varman and disappeared from our sights before the emergence of Kumāravarman's earliest recorded ancestor.
43 Complex hypothetical scenarios can, of course, be drawn up but would require further evidence. For example, Kumāravarman's dynasty may have descended from the Mānavāyanis along the male line but from the Later Aulikaras along the maternal line, and appropriated the name Aulikara after the waning of the Later Aulikaras. 